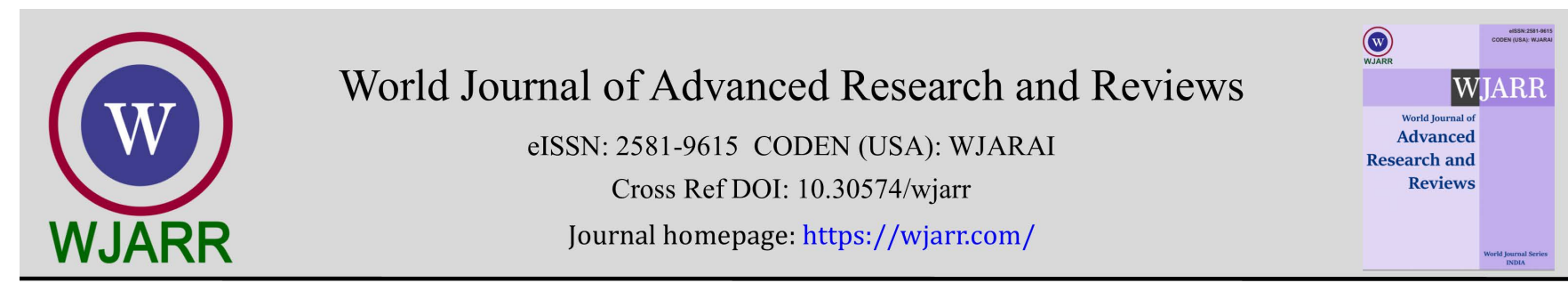

(REVIEW ARTICLE)

\title{
Implications of industrial effluents on surface water and ground water
}

\author{
Abdullateef Abdullahi Ibrahim ${ }^{1,}{ }^{*}$, Muhammad Abdullahi Ibrahim ${ }^{1}$ and Ali Gambo Yusuf ${ }^{2}$ \\ ${ }^{1}$ Department of Biological Sciences, Faculty of Science, University of Maiduguri, P.M.B. 1069, Borno, Nigeria. \\ 2 Department of Biochemistry, Faculty of Science, University of Maiduguri, P.M.B. 1069, Borno, Nigeria.
}

World Journal of Advanced Research and Reviews, 2021, 09(03), 330-336

Publication history: Received on 15 February 2021; revised on 19 March 2021; accepted on 21 March 2021

Article DOI: https://doi.org/10.30574/wjarr.2021.9.3.0110

\begin{abstract}
The industrial discharge carries significant level of contaminants to the surface water and ground water. Whereas the quality of freshwater is very vital because is highly use by human for drinking, bathing, agriculture and other needs. The presence of contaminants from industries within the water may reduce the yield of crops and the growth of plants; it is also harmful to the aquatic living organisms, it alters the surface water and ground water quality. Industrial pollution is one of the major factors causing degradation of the environment, affecting the water we use, the air we breathe and the soil we live on. Hence, the pollution of water is arguably the most serious threat to current human welfare. This paper review elucidates reasons of contamination of surface water by the industrial effluents, highlights major causes of ground water pollution; the work also indicates some industrial discharges and their contaminants.
\end{abstract}

Keywords: Industrial effluents; Ecosystems; Pollution; Environment; Contaminants

\section{Introduction}

Effluents coming from different industrial and commercial establishments have being posing serious threats to the environment, particularly in urban and semi urban areas [1]. Meanwhile, it was estimated that approximately one-third (1/3) of the world's population are using groundwater for drinking purposes [2].

The discharge of effluents from pharmaceutical industries into the environment could easily lead to the contamination of surface water and ground water with diverse drug active ingredients, the long effect of which may be harmful to the health of those that use the water [3].

Due to recent industrialisation and ever increasing urbanisation, the quality of surface water and ground water has become a matter of major concern because of heavy metal contamination. Metals remain in contaminated sediments may accumulate in microorganisms which in return enter into the food chain and eventually affect human well being [4].

Contamination of water by trace metals is a serious health issue. Studies have shown that heavy metal toxicity leads to cardiovascular, neurological and renal problems; the main health hazards caused by chemical pollution of water are due to presence of nitrates fluorides, arsenic, cadmium, lead and other toxic metals [5].

\section{Why always Surface water is the Victim of the Industrial Effluents}

One of the major reasons as specified by Bassi et al. [6] is limited financial and technical support from the government that led to poor maintenance of few lakes while many lakes are completely neglected. Yet another important factor is

\footnotetext{
* Corresponding author: Abdullateef Abdullahi Ibrahim; Phone: +(234) 7083333163; E-mail: abdullateefgaya@gmail.com Department of Biological Sciences, Faculty of Science, University of Maiduguri, P.M.B. 1069, Borno, Nigeria. 
the poor understanding about the link between water and ecological health, ecosystem services and human well-being [7]. As an outcome, many urban and rural lake catchments are encroached, ground water is over exploited and surface and ground water are polluted due to household and industrial discharges. Changing water quality has implication on livelihoods and well-being of lake dependent communities [8]. Untreated waste from industries has a number of reasons of not safely treated; One of the reasons is mainly due to the lacking of highly efficient and economic treatment technology [2]. Water pollution is a major problem in the global context, and it has been reported that it is the leading worldwide cause of deaths and diseases [9].

\subsection{Ground Water and Surface Water Pollution}

Groundwater pollution can be caused by three major sources according to TWAS [10] which are:

- Weathering of soil and rock minerals,

- Decomposition of organic materials and

- Industrial effluents, sewerage and municipal waste water.

Surface water is a vital source of irrigation, household usages. However, the discharges of untreated industrial wastes have been deteriorating the quality of the surface water.

Ground water is the most important source of drinking water. At present almost all depends on ground water for drinking purpose. According to Hossain, et al. [1] in a research titled; Impact of Industrial Effluents Discharges on Degradation of Natural Resources and Threat to Food Security found that the presence of insignificant proportion (4\%) of untreated industrial effluent decreases the quality of ground water.

Copacui et al. [11] asserted in his study titled; Assessment of Industrial Effluents Quality and their Possible Impact on Surface Water indicated a seasonal variation for several parameters, dictated by the manufacturer' production schedule. Reported the quality of the studied effluents was below the limits set by UE and Romanian legislation. The total dissolved solids (TDS), sulphate, chloride and detergents content of the effluents were within the permissible limits for surface water discharge, while the other parameters exceeded the limits set by the legislation. The most significant permissible limit excesses were recorded in the printing effluents and the second textile proving that their discharge into some rivers or the sewage systems can seriously affect the aquatic ecosystems.

Various parameters of industrial effluents such as temperature, $\mathrm{pH}$, total dissolved solids (TDS), electrical conductivity (EC) and heavy metal contents (i.e., $\mathrm{Cr}, \mathrm{Fe}, \mathrm{Cd}, \mathrm{Cu}, \mathrm{Mn}, \mathrm{Pb}, \mathrm{Ni}$ and $\mathrm{Zn}$ ) have been found higher than normal at the discharge point of the industries [12].

Muhammad et al. [13] asserted in the study which focused on analyzing industrial effluents originating from industrial estate of Islamabad (the capital city of Pakistan); where dominant tree-species of Islamabad such as Grevillea robusta, Bauhinia variegate, Acacia modesta, Cassia fistula, Syzygium cumini (Skeels), Terminalia arjuna (Roxburgh), Albizia lebbeck (Benth), Melia azedarach and Pongamia pinnata were selected to examine the tolerance of these tree-species against industrial effluents; One year old uniform saplings of nine (9) selected species were transplanted into soil filled polythene tubes for the experiment. The collected samples of effluents were analyzed for water quality parameters such as $\mathrm{pH}$, total dissolved solids, electrical conductivity and heavy metals concentration. The pH of effluent sample was low (acidic) whereas total dissolved solids and electrical conductivity were higher than described FAO standards for irrigation water. The results also indicated higher concentration of heavy metals ( $\mathrm{Pb}, \mathrm{Mn}, \mathrm{Cr}, \mathrm{Cd}, \mathrm{Zn}, \mathrm{Mg}$ and $\mathrm{Ni}$ ) in the industrial effluents. Saplings were irrigated with assorted water treatments and their effects on shoot and leaf growth was observed; the analysis of the data showed decline in growth of all tree species irrigated with effluent based treatments. However, Syzygium cumini, Acacia modesta, Melia azedarach, Albizia lebbeck and Terminalia arjuna relatively performed better and indicated tolerance against industrial effluents. Therefore, Muhammad et al. [13] recommended that these species Dharek, Arjun, Jaman, Siris and Phulai, may be planted along industrial drains.

\section{Industrial discharge and contaminants}

The table below presents a summary of the some types of contaminants discharged from the industries in different parts of the world through random case studies by Ho et al. [2]. 
Table 1 Contaminants Discharge from Different Types of Industry and Location.

\begin{tabular}{|c|c|c|}
\hline Location & Contaminant & Type of industry \\
\hline Bangladesh, to Lagoon [14] & $\begin{array}{l}\text { Metalloid } \\
\text { As } \\
\text { Metal } \\
\text { Zn, Cu, Strontium (Sr), Pb, Nickel (Ni), } \\
\mathrm{Cr} \text {, Lithium (Li), Vandadium (V), Silver } \\
\text { (Ag), Cobalt (Co), Selenium (Se) } \\
\text { Organic/inorganic matter and } \\
\text { parameter } \\
\text { Biochemical oxygen demand (BOD), } \\
\text { chemical oxygen demand (COD), } \\
\text { electrical conductivity, pH, total } \\
\text { alkalinity, total hardness, total organic } \\
\text { carbon (TOC), Turbidity (Cl-), total } \\
\text { suspended solids (TSS) and total } \\
\text { dissolved solids (TDS). }\end{array}$ & $\begin{array}{l}300 \text { industries included textile, } \\
\text { dyeing to plastics, metal } \\
\text { fabrications, semiconductor } \\
\text { goods, lather tanning etc. }\end{array}$ \\
\hline Japan, to Nishitakase River [15] & $\begin{array}{l}\text { 2-[2-(acetylamino)-4-[bis(2- } \\
\text { methoxyethyl) amino -5- } \\
\text { methoxyphenyl]-5-amino-7- bromo-4- } \\
\text { chloro-2-H-benzotriazole (PBTA-1) }\end{array}$ & Textile industry \\
\hline $\begin{array}{l}\text { Germany, to three rivers of } \\
\text { North Rhine- Westphalia [16] }\end{array}$ & $\begin{array}{l}\text { Organic/ inorganic matter and } \\
\text { parameter } \\
\text { (i) Chemical process site } 1 \\
\text { Dichloroaniline } \\
\text { Tetramethylbutanedinitrile } \\
\text { Tributylphosphate } \\
\text { Triethylphosphate } \\
\text { Diisopropylnaphthalenes } \\
\text { Benzoic acid } \\
\text { 2,2,4-Trimethyl-1,3 } \\
\text { pentanedioldiisobutyrat (TXIB) } \\
\text { (ii) Meat production site and } \\
\text { chemical site } \\
\text { N, N-dibenzylamine } \\
\text { 1-methyl-2-indolinone } \\
\text { N,N-Dibenzylamine } \\
\text { Triethyl phosphate (TEP) } \\
\text { Trimethyl- and 4-tertbutylbenzoic } \\
\text { 2-(Chloromethyl)-1,3-dioxolan } \\
\text { 1-Methyl-2-indolinon, } \\
\text { Trimethylbenzoic acid, } \\
\text { Tris(chloro-propyl) phosphat } \\
\text { (TCPP) } \\
\text { (iii) Oil production sites and } \\
\text { chemical complex } \\
\text { Tributylamine, Dimethylpyridine, }\end{array}$ & $\begin{array}{l}\text { Petrochemical site, paper } \\
\text { production, meat production }\end{array}$ \\
\hline
\end{tabular}




\begin{tabular}{|c|c|c|}
\hline & $\begin{array}{l}\text { Dimethylpyrazine, } \\
\text { Indole } \\
\text { Methylindole } \\
\text { 1-Ethylpyrrolidone Thioanisole } \\
\text { Methylphenyl sulfone, TCPP, } \\
\text { Isomer } 1 \\
\text { TCPP, Isomer } 2 \\
\text { C1 Benzoic acid } \\
\text { C2 Benzoic acid } \\
\text { 2,4,6-Trimethylbenzoic acid }\end{array}$ & \\
\hline $\begin{array}{l}\text { Kingdom of Saudi Arabia, to Red } \\
\text { Sea [17] }\end{array}$ & $\begin{array}{l}\text { Metal } \\
\mathrm{Cd}, \mathrm{Cr}, \mathrm{Cu} \text {, Iron (Fe), } \mathrm{Ni}, \mathrm{Pb}, \mathrm{Zn} \text {, } \\
\text { Aluminium ( } \mathrm{Al} \text { ), Barium (Ba), } \\
\text { Molybdenum (Mo), Strontium ( } \mathrm{Sr} \text { ) } \\
\text { Organic/ inorganic matter and } \\
\text { parameter } \\
\text { Benzene, styrene, toluene, indene, } \\
\text { Naphthalene, 1, 4-dioxane, Ethyl } \\
\text { Benzene, Xylene }\end{array}$ & $\begin{array}{l}\text { Two petrochemicals, three } \\
\text { Refineries }\end{array}$ \\
\hline India, to agriculture field [18] & $\begin{array}{l}\text { Metal } \\
\mathrm{Cd}, \mathrm{Cu}, \mathrm{Fe}, \mathrm{Ni}, \mathrm{Pb}, \mathrm{Zn} \\
\text { Organic/ inorganic matter and } \\
\text { parameter } \\
\mathrm{BOD}, \mathrm{COD}, \mathrm{TDS} \text {, dissolved solids (DS) } \\
\text { Chloride, sulphate, phosphate }\end{array}$ & Paper Industry \\
\hline India, to Uppanar river [19] & $\begin{array}{l}\text { Metal } \\
\mathrm{Fe}, \mathrm{Mn}, \mathrm{Pb}, \mathrm{Zn}, \mathrm{Cu}, \mathrm{Ni}, \mathrm{Cr}, \mathrm{Cd}, \mathrm{Co} \\
\text { Organic/inorganic matter and } \\
\text { parameter } \\
\mathrm{DO}, \mathrm{COD}\end{array}$ & $\begin{array}{l}\text { Chemicals, beverage } \\
\text { manufacturing, tanneries, oil, } \\
\text { soap, paint production, paper, } \\
\text { and metal processing plants }\end{array}$ \\
\hline Croatia, to Sava River [20] & $\begin{array}{l}\text { Metal } \\
\mathrm{Fe}, \mathrm{Zn}, \mathrm{Cu}, \mathrm{Ni}, \mathrm{Pb}, \mathrm{Cr}\end{array}$ & $\begin{array}{l}\text { Pharmaceutical and food } \\
\text { Industries }\end{array}$ \\
\hline India, to Bandi River [21] & $\begin{array}{l}\text { Metal } \\
\mathrm{Cu}, \mathrm{Fe}, \mathrm{Zn} \text { and Mn } \\
\text { Organic/inorganic matter and } \\
\text { parameter } \\
\text { TDS, TSS, COD, BOD, chlorides, } \\
\text { sulphates, carbonates and sodium, } \\
\text { calcium and magnesium }\end{array}$ & Dyeing and printing industries \\
\hline Malaysia, to Juru River [22] & $\begin{array}{l}\text { Metalloid } \\
\text { Arsenic (As) } \\
\text { Metal } \\
\text { Chromium (Cr), Cadmium (Cd), } \\
\text { Zinc (Zn), Copper (Cu), Lead (Pb), } \\
\text { Mercury (Hg) }\end{array}$ & $\begin{array}{l}\text { Chemical products } \\
\text { Papers and printings } \\
\text { Batteries } \\
\text { Electroplating } \\
\text { Textile and leathers } \\
\text { Fertilizers, pesticides, } \\
\text { insecticides }\end{array}$ \\
\hline
\end{tabular}




\begin{tabular}{|c|c|c|}
\hline & $\begin{array}{l}\text { Organic/ inorganic matter and } \\
\text { parameter } \\
\text { Phosphate }\left(\mathrm{PO}_{4}^{3-}\right) \\
\text { Ammonia }\left(\mathrm{NH}_{3}\right) \\
\text { Nitrate }\left(\mathrm{NO}^{3-}\right) \\
\text { Sulphates }\left(\mathrm{SO}_{4}^{2-}\right) \\
\text { Chloride }\left(\mathrm{Cl}^{-}\right) \\
\text {Aluminium }(\mathrm{Al})\end{array}$ & $\begin{array}{l}\text { Plastic-based products } \\
\text { Rubber-based products } \\
\text { Wood based products } \\
\text { Electric and electronic industries } \\
\text { Cosmetics } \\
\text { Fungicides } \\
\text { Fluorescent lights } \\
\text { Dental amalgams } \\
\text { Art supplies } \\
\text { Mining and siltation } \\
\text { Cement and cement products } \\
\text { Iron, steel and tin workshops } \\
\text { Welding fumes } \\
\text { Medical equipment } \\
\text { Smelting plants } \\
\text { Metal fabrications } \\
\text { Oil refineries } \\
\text { Quarries } \\
\text { Beverages and food }\end{array}$ \\
\hline India, to unlined lagoon [23] & $\begin{array}{l}\text { Organic/ inorganic matter and } \\
\text { parameter } \\
\text { Sodium, chloride, calcium, COD, } \\
\text { BOD }\end{array}$ & Cystine production industry \\
\hline $\begin{array}{l}\text { Bompai-Jakara drainage basin } \\
\text { Kano [24] }\end{array}$ & $\begin{array}{l}\text { Metals } \\
\mathrm{Zn}, \mathrm{Pb}, \mathrm{Cr}, \mathrm{Fe}, \mathrm{Cu}\end{array}$ & $\begin{array}{l}\text { Industrial effluents, } \\
\text { wastewater from tributaries, } \\
\text { domestic wastewater }\end{array}$ \\
\hline
\end{tabular}

The study shows that most of the industrial discharge carries toxic substances. Due to the presence of high amount of toxic, carcinogen, and teratogen of heavy metals, researchers are highly concerned with its effect on the environment and health of mankind.

\section{Conclusion}

A clean and healthy environment is important for the survival and well-being of living organisms. Ecosystem is degrading gradually due to heavy industrialisation; contaminants from various industries have damaging effects on both flora and fauna.

Therefore, industrial effluents need to be treated properly before their discharge into sewerage network or the surface water in order to minimise their effect on the terrestrial and aquatic ecosystems.

\section{Compliance with ethical standards}

\section{Acknowledgments}

This research was supported by Petroleum Technology Development Fund (PTDF). We are short of words to express our gratitude to PTDF for their continued encouragement by awarding us scholarship at M Sc level. We offer our sincere appreciation for the award that enables us to write this paper. Thank you very much for the support.

\section{Disclosure of conflict of interest}

All authors declare that they have no conflict of interest. 


\section{References}

[1] Hossain MA, Khabir-Uddin M, Molla AH, Afrad M.S I, Rahman MM, Rahman GKMM. sImpact of Industrial Effluents Discharges on Degradation of Natural Resourcesand Threat to Food Securit. A Scientific Journal of Krishi Foundation. 2010; 8 (2): 80.

[2] Ho YC, Show KY, Guo, NI, Alkarkhi AFM, Morad N. Industrial Discharge and Their Effect to the Environment, Industrial Waste, Prof. Kuan-Yeow Show (Ed.), 2012; ISBN: 978-953-51-0253-3, InTech.

[3] Babatunde AI, Bamgbola EP, Oyelola OT. The Effect of Pharmaceutical Effluents on the Quality of Groundwater: A Case Study of Ikeja Industrial Area of Lagos, Nigeria. International Journal of Research In Medical and Health Sciences. 2014; 4 (1): 1.

[4] Shakeri A, Moore F. The Impact of an Industrial Complex on Freshly Deposited Sediments, Chener Rahdar River Case Study, Shiraz, Iran. Environmental Monitoring and Assessment. 2010; 169 (1): 321-334.

[5] CGWB Central Ground Water Board, Brochure, Jaipur District. 2013.

[6] Bassi N, Kumar MD, Sharma A, Pardha-Saradhi P. Status of Wetlands in India: A Review of Extent, Ecosystem Benefits, Threats and Management Strategies, Journal of Hydrology: Regional Studies. 2014; 2: 1-19.

[7] Gleick PH. A Look at Twenty-First Century Water Resources Development. Water International. 2000; 25(1): 127138.

[8] Hemamalini J, Mudgal BV, Sophia JD. Effects of domestic and industrial effluent discharges into the lake and their impact on the drinking water in Pandravedu village, Tamil Nadu, India, Global NEST Journal. 2017; 19(2): 225231.

[9] World resources, A guide to the Global Environment, Environmental Change and Human Health. 1998 ; (1): 386.

[10] Third World Academy of Sciences-TWAS, Safe Drinking Water The need, the problem, solutions and an action plan, Third World Academy of Sciences, Trieste Italy. 2002.

[11] Copaciu F, Carmen R, Ocsana O, Andrea B, Vioara M. Assessment of Industrial Effluents Quality and their Possible Impact on Surface Water. Bulletin UASVM Animal Science and Biotechnologies. 2015; 72(2): 130.

[12] Singh R. Effluents Quality of Woollen Industrial Units and Efficiency of Wastewater Treatment Plant at Jorbir, Bikaner, Rajasthan (India), Orient., J. Chem, 2014; 30(1): 49-56.

[13] Muhammad FB, Ashraf MI, Masoom Z, Malik SU. Impact of Industrial Effluents on Growth of Dominant Tree Species of Islamabad, Pakistan. Pak. J. Bot. 2017; 49(5): 1833-1839.

[14] Ahmed G, Miah MA, Anawar HM, Chowdhury DA, Ahmad JU. Influence of Multi-Industrial Activities on Trace Metal Contamination: An Approach towards Surface Water Body in the Vicinity of Dhaka Export Processing Zone (DEPZ). Environmental Monitoring and Assessment. 2011; 1: 1-10.

[15] Shiozawa T, Suyama K, Nakano K, Nukaya H, Sawanishi H, Oguri A. Mutagenic Activity of 2-Phenylbenzotriazole Derivatives Related to a Mutagen, PBTA-1, in River Water. Mutation Research/Genetic Toxicology and Environmental Mutagenesis. 1999; 442(2): 105-111.

[16] Botalova O, Schwarzbauer J. Geochemical Characterization of Organic Pollutants in Effluents Discharged from Various Industrial Sources to Riverine Systems. Water, Air, \& Soil Pollution. 2011; 1: 1-22.

[17] Ahmad M, Bajahlan AS, Hammad WS. Industrial Effluent Quality, Pollution Monitoring and Environmental Management. Environmental Monitoring and Assessment. 2008; 147 (1): 297-306.

[18] Devi NL, Yadav IC, Shihua Q, Singh S, Belagali S. Physicochemical Characteristics of Paper Industry Effluents - A Case Study of South India Paper Mill (SIPM). Environmental Monitoring and Assessment. 2010; 1: 1-11.

[19] Jonathan M, Srinivasalu S, Thangadurai N, Ayyamperumal T, Armstrong-Altrin J, Ram-Mohan V. Contamination of Uppanar River and Coastal Waters off Cuddalore, Southeast Coast of India. Environmental Geology. 2008; 53(7): 1391-1404.

[20] Radic S, Stipaniev D, Cvjetko P, Mikeli IL, Raji MM, Irac S. Ecotoxicological Assessment of Industrial Effluent Using Duckweed (Lemna minor L.) as a Test Organism. Ecotoxicology. 2010; 19(1): 216-222.

[21] Singh N, Sharma B, Bohra P. Impact Assessment of Industrial Effluent of Arid Soils by Using Satellite Imageries. Journal of the Indian Society of Remote Sensing. 2000; 28(2): 79-92. 
[22] Al-Shami SA, Rawi CSM, Hassan AA, Nor SAM. Distribution of Chironomidae (Insecta: Diptera) in Polluted Rivers of the Juru River Basin, Penang, Malaysia. Journal of Environmental Sciences. 2010; 22(11): 1718-1727.

[23] Gowd S, Kotaiah B. Groundwater Pollution by Cystine Manufacturing Industrial Effluent around the Factory. Environmental Geology. 2000; 39(6): 679-682.

[24] Imam TS. Assessment of Heavy Metals Concentrations in the Surface Water of Bompai-Jakara Drainage Basin, Kano State, Northern Nigeria, Bayero Journal of Pure and Applied Sciences. 2012; 5(1): 103 - 108. 